Original Article

\title{
The influence of primer choice on archaeal phylogenetic analyses based on 165 rRNA gene PCR
}

\author{
A influência da escolha de iniciadores na filogenia de Archaea em ensaios de PCR para \\ o gene rRNA 16S
}

\author{
A. Belmok (D), T. Rodrigues-Oliveira ${ }^{\mathrm{a}}$ (D), F.A.C. Lopes $^{\mathrm{b}}$ (D), R.H. Krüger ${ }^{\mathrm{a}}$ (D), C.M. Kyaw ${ }^{\mathrm{a} *}$ (D) \\ aUniversidade de Brasília - UnB, Instituto de Ciências Biológicas, Departmento de Biologia Celular, Brasília, DF, Brasil \\ bUniversidade Federal do Tocantins - UFT, Laboratório de Microbiologia, Porto Nacional, TO, Brasil
}

\begin{abstract}
Polymerase chain reaction (PCR) assays targeting $16 \mathrm{~S}$ rRNA genes followed by DNA sequencing are still important tools to characterize microbial communities present in environmental samples. However, despite the crescent number of deposited archaeal DNA sequences in databases, until now we do not have a clear picture of the effectiveness and specificity of the universal primers widely used to describe archaeal communities from different natural habitats. Therefore, in this study, we compared the phylogenetic profile obtained when Cerrado lake sediment DNA samples were submitted to $16 \mathrm{~S}$ rDNA PCR employing three Archaea-specific primer sets commonly used. Our findings reveal that specificity of primers differed depending on the source of the analyzed DNA. Furthermore, archaeal communities revealed by each primer pair varied greatly, indicating that 16S rRNA gene primer choice affects the community profile obtained, with differences in both taxon detection and operational taxonomic unit (OTU) estimates.
\end{abstract}

Keywords: Archaea, PCR, universal primers, environmental microbiology.

\begin{abstract}
Resumo
A amplificação de genes que codificam o rRNA $16 \mathrm{~S}$ por reação em cadeia da polimerase (PCR) e o seu subsequente sequenciamento consistem em uma ferramenta importante na caracterização de comunidades microbianas presentes em amostras ambientais. No entanto, apesar do crescente número de sequências de DNA de Archaea depositadas em bancos de dados, a especificidade e efetividade dos iniciadores de PCR descritos como universais e amplamente utilizados na descrição desse grupo ainda não está clara. Neste estudo foram comparados os perfis filogenéticos de comunidades de arqueias obtidos a partir amostras de DNA de sedimentos lacustres do Cerrado submetidas a ensaios de PCR empregando três pares de iniciadores específicos para Archaea, comumente utilizados neste tipo de estudo. Nossos resultados indicam que as comunidades de arqueias detectadas com cada par de iniciadores apresentaram grande variação filogenética, sugerindo que a escolha de iniciadores dirigidos ao gene de rRNA $16 \mathrm{~S}$ tem efeito significativo no perfil da comunidade descrita, com diferenças tanto em relação aos táxons detectados, como nas estimativas de unidades taxonômicas operacionais (OTU).
\end{abstract}

Palavras-chave: Archaea, PCR, iniciadores universais, microbiologia ambiental.

\section{Introduction}

It has been extensively documented that the vast majority of existing microbial diversity consists of yet uncultured organisms (Rappé and Giovannoni, 2003; Lloyd et al., 2018). To access this diversity, molecular biology techniques have become a valuable asset to explore microbial communities in environmental samples. Several methods have been employed throughout the years, such as denaturing gradient gel electrophoresis (DGGE), restriction fragment length polymorphism (RFLP), clone libraries of polymerase chain reaction (PCR) amplicons, quantitative PCR and, more recently, metagenome assembly using next generation sequencing (Streit and Schmitz, 2004; GarridoCardenas and Manzano-Agugliaro, 2017). As a result, our knowledge on the diversity and metabolic potential of yet uncultured groups has greatly improved in the last years, with the description of several novel taxa and the proposal of entire phyla with no cultured representatives, greatly affecting both bacterial and archaeal phylogeny (Hug et al., 2016).

Among the methods most frequently employed in environmental studies, PCR assays targeting conserved genes have played pivotal roles both in pioneer and

*e-mail: malta@unb.br

Received: January 13, 2021 - Accepted: May 7, 2021

This is an Open Access article distributed under the terms of the Creative Commons Attribution License, which permits unrestricted use, distribution, and reproduction in any medium, provided the original work is properly cited. 
recent studies (Muyzer et al., 1993; Bahram et al., 2018). Indeed, reports using both clone libraries and next generation sequencing of PCR amplicons are still frequently published (Tupinambá et al., 2016; Antranikian et al., 2017; Wu et al., 2017; Belmok et al., 2019). However, it is widely acknowledged that this approach is not devoid of potential biases, with steps such as DNA extraction, inhibition of, or unspecific DNA amplification, generation of PCR artefacts and differential amplification all playing a crucial role in result analyses (Delmont et al., 2013).

It has been demonstrated that the primers used in $16 \mathrm{~S}$ rRNA gene PCR assays greatly affect the microbial taxa detected in environmental samples (Frank et al., 2008; Hong et al., 2009) and factors such as the DNA flanking the template region may also result in preferential amplification of some sequences (Santos et al., 2019). Indeed, the effectiveness of PCR targeting bacterial 16S rRNA genes to evaluate microbial diversity is subject of a plethora of factors (Acinas et al., 2005; Engelbrektson et al., 2010). Furthermore, despite the great advances in DNA sequencing techniques, biases on 16S rRNA gene-based studies is a topic that still requires attention (Klindworth et al., 2013; Kennedy et al., 2014; Brooks et al., 2015).

Primers described as universal to prokaryotic $16 \mathrm{~S}$ rRNA gene have been demonstrated to be not as effective for the Archaea domain (Kolganova et al., 2002; Baker et al., 2003), reinforcing the utmost importance of adequate archaealspecific primer design (Baker et al., 2003; Gantner et al., 2011). Since most studies comparing prokaryotic $16 \mathrm{~S}$ rDNA-based methods were performed with Bacteria, little is known about the biases associated with the Archaea domain. Therefore, in the present study we compared the phylogenetic profile obtained when a Cerrado lake sediment DNA sample was submitted to 16S rDNA PCR employing widely used Archaea-specific primers.

\section{Material and Methods}

\subsection{DNA Samples}

Lake sediment samples were collected in native Cerrado (a Brazilian savannah-like biome) and used in this study. Sediment samples were obtained from a lake known as "Lagoa Rio Preto Alto" (LRPA) in the "Sempre Vivas" National Park, located in the state of Minas Gerais, Brazil, on May 2010 (FAP-DF project 2009/00086-7). Sampling was performed using $10 \mathrm{~cm}$ diameter PVC tubes, by introducing the tube up to $5 \mathrm{~cm}$ into sediments $1 \mathrm{~m}$ below the lake`s water level.

\subsection{DNA extraction, PCR conditions and 16S rRNA genes libraries construction}

DNA was extracted from $0.5 \mathrm{~g}$ of each sample with PowerSoil DNA Isolation Kit (MO Bio Laboratories Inc.) according to the manufacturer's instructions. PCR assays were conducted for each sample with three different primer combinations: 21f/958r (5'TTCCGGTTGATCCYGCCGGA-3') 5'YCCGGCGTTGAMTCCAATT 3') (DeLong, 1992), 109f/915r (5’ACKGCTCAGTAACACGT-3’) 5’GTGCTCCCCCGCCAATTCCT-3’) (Großkopf et al.,
1998) and 340f/1000r (5'CCCTAYGGGGYGCASCAG3'। 5'GGCCATGCACYWCYTCTC-3') (Gantner et al., 2011), all proposed as specific and universal for the 16S rRNA gene of Archaea. These primer sets amplify overlapping regions of the 16S rRNA gene. All PCR assays were performed in $30 \mu \mathrm{L}$ or $50 \mu \mathrm{L}$ reaction mixtures, containing 1 to $100 \mathrm{ng}$ of template DNA, $1 \mathrm{X}$ reaction buffer (Invitrogen), $1.5 \mathrm{mM}$ $\mathrm{MgCl}_{2}$ (Invitrogen), $400 \mathrm{ng} / \mu \mathrm{L}$ bovine serum albumin (BSA), $0.5 \mu \mathrm{M}$ of each primer, $200 \mu \mathrm{M}$ dNTPs (Invitrogen), 1.5 U Taq DNA Polymerase (Invitrogen). The following PCR conditions were used for primers 21f-958r and 109f-915r: initial denaturation at $94^{\circ} \mathrm{C}$ for $1 \mathrm{~min}$, followed by 30 cycles consisting of denaturation $\left(94^{\circ} \mathrm{C}\right.$ for $\left.1 \mathrm{~min}\right)$, annealing ( $1 \mathrm{~min})$ and extension $\left(72^{\circ} \mathrm{C}\right.$ for $1 \mathrm{~min}$ and $\left.30 \mathrm{~s}\right)$ and a final extension step at $72^{\circ} \mathrm{C}$ for $5 \mathrm{~min}$. Annealing temperatures were 55 and $57^{\circ} \mathrm{C}$ for primer pairs $21 \mathrm{f}-958 \mathrm{r}$ and $109 \mathrm{f}-915 \mathrm{r}$, respectively. PCR conditions used for amplification of LRPA with primers $340 \mathrm{f}-1000 \mathrm{r}$ were the same described by Gantner et al. (2011). All PCR experiments were performed in a MJ PTC-100 (Peltier Thermal Cycles) thermocycler.

Amplified DNA was visualized on $1 \%$ agarose gels electrophoresis stained with ethidium bromide $(0.5 \mu \mathrm{g} / \mathrm{mL})$. Amplicons were purified using GeneJET PCR Purification kit (Thermo Scientific), cloned into pGEM-T Easy ${ }^{\circledR}$ (Promega) vector, according to manufacturer's instructions, and transformed into Escherichia coli DH5 a competent cells by heat shock treatment. Plasmidial DNA of the recombinant clones was extracted by phenol-chloroform-isoamyl alcohol at 25:24:1 (vol/vol/vol) and sequenced by Sanger method at Macrogen Inc. (Korea).

\subsection{DNA Sequences analyses and primers coverage in silico analysis}

The quality of the DNA sequences obtained was checked with Phred algorithm (http://asparagin.cenargen.embrapa. $\mathrm{br} / \mathrm{phph} /$ ) and only those with quality superior to 20 in more than 400 nucleotides were considered for further analyses. Chimeric sequences were identified by UCHIME 2 , through the NCBI platform. Taxonomic classification of the sequences was performed with the latest releases of Greengenes (13_8) (DeSantis et al., 2006) and SILVA (v132) (Quast et al., 2013) taxonomical databases, both using Mothur v.1.24.1 (Schloss et al., 2009), and with the Ribosomal Data Project (RDP) tool on https://rdp.cme. msu.edu/classifier/classifier.jsp. Only identity thresholds of $90 \%$ or higher were considered.

Multiple alignments of 16S rRNA gene sequences amplified with different primers sets were performed separately with Clustal X v. 2.1 (Larkin et al., 2007) and gap columns generated were manually filtered. Mothur was used to calculate richness and diversity indexes, coverage estimations, as well as unique and shared OTUs at $97 \%$ identity for the construction of Venn diagrams. Shared and exclusive OTUs were estimated based on analysis of overlapping region of the sequences amplified by the different primers.

In silico evaluation of the primer pairs was performed using the online tool TestPrime1.0 (Klindworth et al., 2013) and the non-redundant SILVA database (SSU r138) (Quast et al., 2013). Aiming a more realistic simulation of 
PCR behavior, one mismatch per primer at all locations except at the five bases of the 3'end was allowed (Klindworth et al., 2013).

\subsection{Nucleotide sequence accession numbers}

The nucleotide sequences from this study were deposited in the GenBank database under accession numbers MK527511-MK527839.

\section{Results and Discussion}

Three different primer pairs described as universal and specific for archaeal 16S rRNA genes were used to amplify a sediment environmental DNA sample (LRPA). Clone libraries of $16 \mathrm{~S}$ rRNA genes amplified with each of the three selected primer combinations were obtained for the lake sediment DNA sample, totalizing three libraries (LRPA 21f-958r, LRPA 109f-915r and LRPA 340f-1000r). Despite the similar number of sequenced clones in each library, the number of sequences that were classified as Archaea after quality and chimera analyses was highly different among primer pairs (Table 1 ).

All 16S rDNA sequences detected with primers 21f-958r were classified as Archaea (Table 1), suggesting a high specificity of this primer combination for archaeal DNA sequences present in our sample. In contrast, primers 109f-915r were less specific, and amplified two bacterial sequences. Although these primers, originally designed to describe methanogens (Großkopf et al., 1998), have been extensively used to describe archaeal communities (Nishizawa et al., 2008; Jeyanathan et al., 2011; Carnevali et al., 2018), previous results of our group revealed that they are effective in the amplification of bacterial DNA sequences, especially when these organisms are present in higher abundance in environmental samples (data not shown).

Considering the current archaeal phylogeny and taxonomy proposed in the literature, classifications obtained with SILVA seemed more adequate, especially at the lower taxonomic levels, as it considers nomenclatures currently employed for many uncultivated groups (e.g. I.1c, Bathyarchaeia, Woesearchaeia), while other databases still present outdated nomenclatures or are not able to classify sequences affiliated to recently proposed taxa. Therefore, classifications obtained with SILVA were selected for further comparisons of the 16S rDNA libraries obtained with the different primer pairs.

As shown in Figure 1, the archaeal communities revealed by each primer pair varied greatly. While sequences amplified with primers 109f-915r and 340f-1000r resulted in similar phyla profiles, with most sequences affiliated to Euryarchaeota, amplicons obtained with primers 21f-958r were mainly associated to Thaumarchaeota and Bathyarchaeota (Figure 1A). In addition, Woesearchaeota could only be detected by 109f-915r and 340f-1000r. At lower taxonomic ranks, differences among the three primer pairs were also observed. With the exception of a few unclassified sequences amplified by $340 \mathrm{f}-1000 \mathrm{r}$, all Euryarchaeota sequences were affiliated to methanogenic orders. While only Methanocellales and Methanosarcinales could be detected by primers $21 \mathrm{f}-958 \mathrm{r}$, three additional methanogenic groups were amplified by $109 \mathrm{f}-915 \mathrm{r}$ and 340f-1000r - Methanobacteriales, Methanomicrobiales and Methanomassillicoccales - in different proportions (Figure 1B). Regarding Thaumarchaeota, 16S rDNA sequences from the yet uncultured subgroup I.1c were only revealed by primers 21f-958r and 109f-915r, while sequences belonging to I.1a (Nitrosotaleales) and I.1b (Nitrososphaerales) were amplified by all primers (Figure 1B).

The archaeal community depicted by primers 109f-915r and 340f-1000r was more comprehensive, revealing a high diversity of archaeal groups usually associated with hypoxic eutrophic freshwater sediments, similar to the one analyzed in the present study (e.g. methanogens) (Castelle et al., 2015; Laskar et al., 2018; Zhou et al., 2018). Interestingly, the archaeal diversity established by primers $21 \mathrm{f}-958 \mathrm{r}$, however, was mainly associated to the TACK superphylum, with many thaumarchaeal sequences, a group not usually reported in lake sediment surveys (Fan and Xing, 2016; Hu et al., 2015). It is worth pointing out that this primer pair also yielded a high number of Bathyarchaeota sequences, a group that has been increasingly demonstrated as fundamental to the ecological dynamics in anoxic environments (Zhou et al., 2018). Thus, while generating fewer amplicons from methanogenic 16S rDNA when compared to the other two pairs, this primer pair provided important insights into this phylum`s diversity.

Despite this fact, such low methanogenic 16S rRNA gene detection in freshwater lake sediments is unusual. One of the main features of these environments is the high abundance of organic matter, especially in the

Table 1. Number of sequenced clones, quality, and classification at domain level of sequences amplified from a lake sediment (LRPA) DNA sample with three different primer pairs.

\begin{tabular}{|c|c|c|c|c|c|c|c|}
\hline Sample/Primers & $\begin{array}{c}\text { № of } \\
\text { sequenced } \\
\text { clones }\end{array}$ & $\begin{array}{c}\text { High } \\
\text { Quality } \\
\text { sequences } \\
(\text { PHRED>31) }\end{array}$ & Chimeras & $\begin{array}{c}\text { Non- } \\
\text { specific } \\
\text { sequences }^{a}\end{array}$ & Bacteriab $^{\mathrm{b}}$ & Archaeab $^{\mathbf{b}}$ & $\begin{array}{c}\text { Percentage of } \\
\text { sequences classified } \\
\text { as } \text { Archaea }^{c}\end{array}$ \\
\hline LRPA $21 \mathrm{f}-958 \mathrm{r}$ & 100 & 84 & 8 & 0 & 0 & 76 & $100.00 \%$ \\
\hline LRPA 109f-915r & 100 & 81 & 14 & 2 & 2 & 63 & $94.02 \%$ \\
\hline LRPA 340f-1000r & 183 & 113 & 1 & 1 & 0 & 111 & $99.10 \%$ \\
\hline
\end{tabular}

a Sequences not identified as $16 \mathrm{~S}$ rDNA (no significant BLAST hits). ${ }^{\mathrm{b}} 16 \mathrm{~S}$ rRNA gene sequences classified with $100 \%$ identity in Greengenes, RDP and SILVA databases. ${ }^{c}$ Percentage of high quality, non-chimeric sequences classified as Archaea. 
A

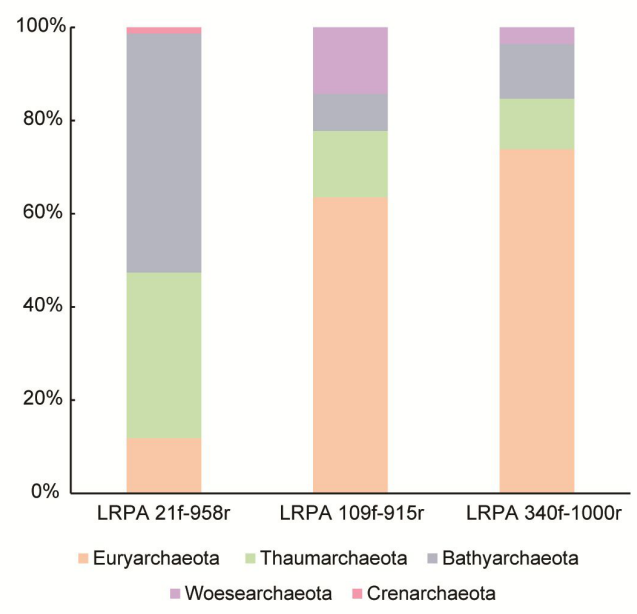

B

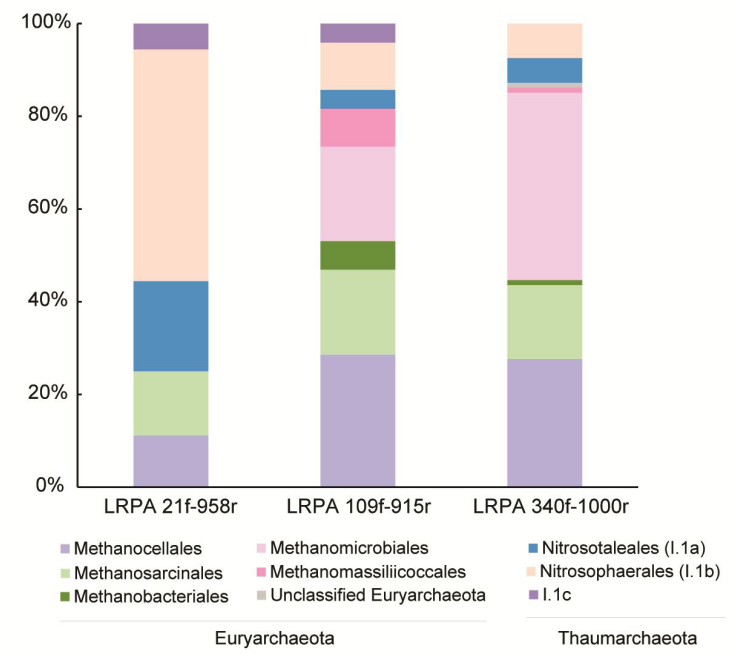

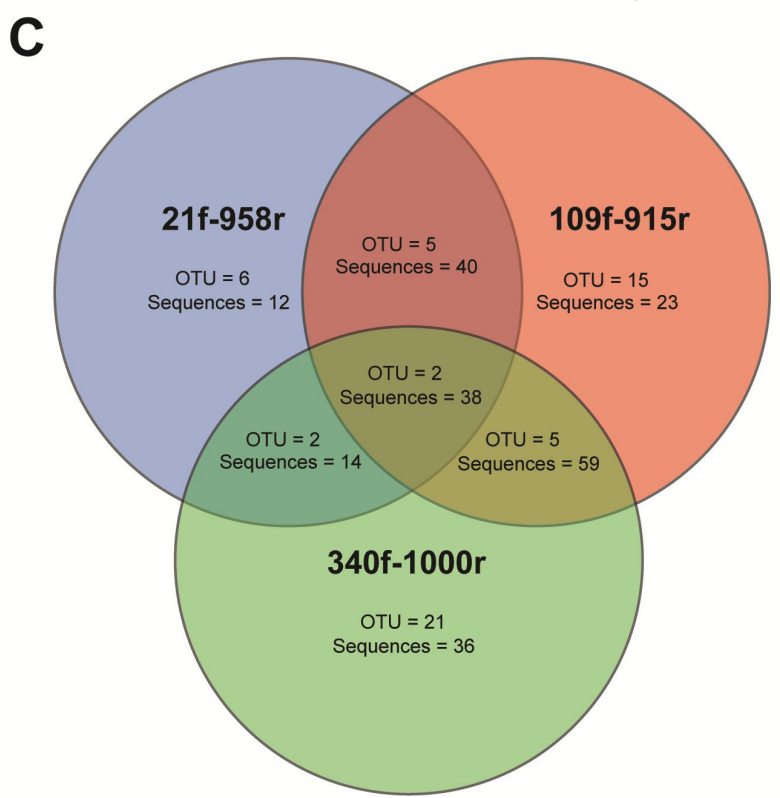

Figure 1. Classification with SILVA database of archaeal $16 \mathrm{~S}$ rRNA sequences amplified from a lake sediment (LRPA) DNA with three different primers sets at phylum level (A) and order level (B). In (C), Venn diagram showing shared and unique OTUs, with 97\% sequence similarity, among sequences amplified from LRPA sample with the three different primers sets.

upper layers (Thomaz et al., 2001; Esteves, 2011). Thus, the decomposition of organic matter plays an important ecological role, where complex molecules are degraded, leading to $\mathrm{H}_{2}, \mathrm{CO}_{2}$ and $\mathrm{CH}_{4}$ formation through microbial activity (Sansone and Martens, 1982). In this context, methanogens are key players in this process, considering that methanogenesis serves as the final step in the anaerobic food chain while also maintaining thermodynamically favorable conditions for fermentative and acetogenic processes (Ferry, 2011). For this reason, methanogens are commonly detected in freshwater lake sediments (Zhu et al., 2012; Rodrigues et al., 2014). Thus, primers $21 \mathrm{f}-958 \mathrm{r}$ are possibly not the most adequate when describing these archaeal communities.
These results are reinforced when compared to in silico assays employing SILVA's TestPrime tool (Table 2) (Klindworth et al., 2013). While it is important to highlight that differences between in vitro and in silico assays are a common occurrence, this analysis indicates that the pair 21f-958r has the lowest taxonomic coverage, being restricted to mainly halophiles and TACK superphylum related groups (e.g. Bathyarchaeia, Nitrososphaeria, Thermoprotei). As previously mentioned, this primer pair yielded a notoriously higher relative abundance of TACK superphylum sequences when compared to methanogens, a result that greatly differs from what would be expected from an ecological standpoint as well as the results obtained with the 109f-915r and 340f-1000r pairs. On the other 
hand, in silico assays indicated that the pair 340f-1000r has the highest taxonomic coverage of the three, with widespread detection across all recognized archaeal taxa by SILVA. Primer pair $109 \mathrm{f}-915 \mathrm{r}$ yielded similar results, though its overall taxonomic coverage was not as high as 340f-1000r. It is also worth pointing out that, as previously mentioned, this primer pair resulted in a few bacterial sequences, something that was not detected on in silico analysis (Table 2). Thus, considering the taxonomic coverage estimations employing the TestPrime tool as well as the results obtained in our in vitro assays, primer pair $340 \mathrm{f}-1000 \mathrm{r}$ is likely best suited to these environments.

OTU based analyses at $97 \%$ sequence similarity revealed great differences when the results obtained in LRPA with the three sets of primers are compared. A low number of shared OTUs among all three libraries and a high number of exclusive OTUs retrieved by each primer pair were observed (Figure 1C). Furthermore, $\alpha$-diversity analyses showed small variations in the Shannon diversity index when each primer pair was used (Table 3), which could

Table 2. Taxonomic coverage of in silico assays of each primer pair used in this study according to the TestPrime tool (SILVA). Taxa covered by each primer pair are shown in bold.

\begin{tabular}{|c|c|c|}
\hline 21f-958r & 109f-915r & $340 f-1000 r$ \\
\hline Archaea (5.0\%) & Archaea (55.1\%) & Archaea $(82.6 \%)$ \\
\hline Aenigmarchaeota & Aenigmarchaeota (13.6\%) & Aenigmarchaeota (37.8\%) \\
\hline Altiarchaeota & Altiarchaeota (64.7\%) & Altiarchaeota (36.0\%) \\
\hline Asgardarchaeota & Asgardarchaeota (5.1\%) & Asgardarchaeota (6.0\%) \\
\hline Crenarchaeota $(0.1 \%)$ & Crenarchaeota (63.8\%) & Crenarchaeota (85.5\%) \\
\hline Bathyarchaeia (0.1\%) & Bathyarchaeia (69.0\%) & Bathyarchaeia (84.8\%) \\
\hline Methanomethylicia & Methanomethylicia (15.2\%) & Methanomethylicia (100.0\%) \\
\hline Nitrososphaeria (0.2\%) & Nitrososphaeria (55.5\%) & Nitrososphaeria (87.2\%) \\
\hline Thermoprotei $(0.3 \%)$ & Thermoprotei (77.3\%) & Thermoprotei (80.7\%) \\
\hline Euryarchaeota & Euryarchaeota (80.1\%) & Euryarchaeota (86.4\%) \\
\hline Methanobacteria & Methanobacteria (80.9\%) & Methanobacteria (87.0\%) \\
\hline Methanococci & Methanococci (88.0\%) & Methanococci (94.4\%) \\
\hline Methanopyri & Methanopyri (100.0\%) & Methanopyri (100.0\%) \\
\hline Thermococci & Thermococci (77.0\%) & Thermococci (81.5\%) \\
\hline Hadarchaeota & Hadarchaeota (2.7\%) & Hadarchaeota (85.8\%) \\
\hline Halobacterota (16.2\%) & Halobacterota (44.0\%) & Halobacterota (89.2\%) \\
\hline Hydrothermarchaeota & Hydrothermarchaeota (86.7\%) & Hydrothermarchaeota (96.8\%) \\
\hline Iainarchaeota & Iainarchaeota (59.4\%) & Iainarchaeota (46.7\%) \\
\hline Korarchaeota & Korarchaeota & Korarchaeota (1.8\%) \\
\hline Micrarchaeota & Micrarchaeota (33.3\%) & Micrarchaeota (55.3\%) \\
\hline Nanoarchaeota & Nanoarchaeota (45.1\%) & Nanoarchaeota (61.4\%) \\
\hline Nanohaloarchaeota & Nanohaloarchaeota & Nanohaloarchaeota (84.8\%) \\
\hline Thermoplasmatota & Thermoplasmatota (67.0\%) & Thermoplasmatota (89.4\%) \\
\hline Uncultured & Uncultured (14.3\%) & Uncultured (80.0\%) \\
\hline Bacteria & Bacteria & Bacteria \\
\hline Eukaryota & Eukaryota & Eukaryota \\
\hline Unclassified & Unclassified & Unclassified \\
\hline
\end{tabular}

Table 3. $\alpha$-Diversity analysis (97\% sequence similarity) of archaeal $16 S$ rRNA gene sequences amplified from a lake sediment (LRPA) sample with three different primer pairs. Archaeal sequences were normalized for the smallest library size $(n=63)$.

\begin{tabular}{cccc}
\hline Primers & Observed OTUs & Shannon & Coverage \\
\hline $21 \mathrm{f}-958 \mathrm{r}$ & 27 & 2.900 & $77.77 \%$ \\
$109 \mathrm{f}-915 \mathrm{r}$ & 29 & 3.141 & $80.95 \%$ \\
$340 \mathrm{f}-1000 \mathrm{r}$ & 21 & 2.522 & $82.54 \%$ \\
\hline
\end{tabular}


lead to different interpretations of a given environment's diversity. It is worth pointing out that the libraries obtained with all three primer pairs had a coverage of around $80 \%$ with the number of sequences analyzed. These results indicate that archaeal $16 \mathrm{~S}$ rRNA gene primer choice greatly affects the community profile obtained, with differences in both taxon detection and OTU estimates.

\section{Conclusions}

Altogether, our results highlight the importance of primer choice when describing archaeal communities in PCR based environmental studies. Domain-specific primer design is a well-recognized challenge, and the commonly used primers analyzed in this study may yield different outlooks on archaeal diversity and phylogeny in a variety of habitats. This aspect should be considered during both experimental design and data analyses. Depending on the community composition and archaeal abundance in a given sample, entire groups could possibly be overlooked and OTU estimations at different taxonomic levels may vary. Therefore, as more 16S rRNA gene sequences are deposited and novel groups are discovered, more comprehensive domain specific primers may be designed for archaea, reducing preferential amplification issues. Thus, while PCR based environmental studies have inherent biases, future studies will surely improve archaeal detection when employing this method.

\section{Acknowledgements}

This research was supported by grants from the National Council of Technological and Scientific Development (CNPq), Brazilian Federal Agency for Support and Evaluation of Graduate Education (CAPES), and Foundation for Research Support of Distrito Federal (FAP-DF). The authors would like to thank Dr Mercedes M. C. Bustamante for sediments collection.

\section{References}

ACINAS, S.G., SARMA-RUPAVTARM, R., KLEPAC-CERAJ, V. and POLZ, M.F., 2005. PCR-induced sequence artifacts and bias: insights from comparison of two 16S rRNA clone libraries constructed from the same sample. Applied and Environmental Microbiology, vol. 71, no. 12, pp. 8966-8969. http://dx.doi.org/10.1128/ AEM.71.12.8966-8969.2005. PMid:16332901.

ANTRANIKIAN, G., SULEIMAN, M., SCHÄFERS, C., ADAMS, M.W.W., BARTOLUCCI, S., BLAMEY, J.M., BIRKELAND, N.K., BONCHOSMOLOVSKAYA, E., COSTA, M.S., COWAN, D., DANSON, M., FORTERRE, P., KELLY, R., ISHINO, Y., LITTLECHILD, J., MORACCI, M., NOLL, K., OSHIMA, T., ROBB, F., ROSSI, M., SANTOS, H., SCHÖNHEIT, P., STERNER, R., THAUER, R., THOMM, M., WIEGEL, J. and STETTER, K.O., 2017. Diversity of bacteria and archaea from two shallow marine hydrothermal vents from Vulcano Island. Extremophiles, vol. 21, no. 4, pp. 733-742. http://dx.doi. org/10.1007/s00792-017-0938-y. PMid:28493148.

BAHRAM, M., ANSLAN, S., HILDEBRAND, F., BORK, P. and TEDERSOO, L., 2018. Newly designed 16S rRNA metabarcoding primers amplify diverse and novel archaeal taxa from the environment. Environmental Microbiology Reports. PMid:30058291.

BAKER, G.C., SMITH, J.J. and COWAN, D.A., 2003. Review and re-analysis of domain-specific $16 \mathrm{~S}$ primers. Journal of Microbiological Methods, vol. 55, no. 3, pp. 541-555. http:// dx.doi.org/10.1016/j.mimet.2003.08.009. PMid:14607398.

BELMOK, A., RODRIGUES-OLIVEIRA, T., LOPES, F.A.C., MIRANDA, H.S., KRÜGER, R.H. and KYAW, C.M., 2019. Long-term effects of periodical fires on archaeal communities from Brazilian Cerrado soils. Archaea, vol. 2019, no. 11, p. 6957210. http:// dx.doi.org/10.1155/2019/6957210. PMid:30833827.

BROOKS, J.P., EDWARDS, D.J., HARWICH JUNIOR, M.D., RIVERA, M.C., FETTWEIS, J.M., SERRANO, M.G., RERIS, R.A., SHETH, N.U., HUANG, B., GIRERD, P., STRAUSS III, J.F., JEFFERSON, K.K. and BUCK, G.A., 2015. The truth about metagenomics: quantifying and counteracting bias in 16S rRNA studies. BMC Microbiology, vol. 15, no. 1, pp. 66. http://dx.doi.org/10.1186/s12866-0150351-6. PMid:25880246.

CARNEVALI, P.B.M., HERBOLD, C.W., HAND, K.P., PRISCU, J.C. and MURRAY, A.E., 2018. Distinct microbial assemblage structure and archaeal diversity in sediments of arctic thermokarst lakes differing in methane sources. Frontiers in Microbiology, vol. 9, pp. 1192. http://dx.doi.org/10.3389/fmicb.2018.01192. PMid:29930542.

CASTELLE, C.J., WRIGHTON, K.C., THOMAS, B.C., HUG, L.A., BROWN, C.T., WILKINS, M.J., FRISCHKORN, K.R., TRINGE, S.G., SINGH, A., MARKILLIE, L.M., TAYLOR, R.C., WILLIAMS, K.H. and BANFIELD, J.F., 2015. Genomic expansion of domain archaea highlights roles for organisms from new phyla in anaerobic carbon cycling. Current Biology, vol. 25, no. 6, pp. 690-701. http://dx.doi. org/10.1016/j.cub.2015.01.014. PMid:25702576.

DELMONT, T.O., SIMONET, P. and VOGEL, T.M., 2013. Mastering methodological pitfalls for surviving the metagenomic jungle. BioEssays, vol. 35, no. 8, pp. 744-754. http://dx.doi.org/10.1002/ bies.201200155. PMid:23757040.

DELONG, E.F., 1992. Archaea in coastal marine environments. Proceedings of the National Academy of Sciences of the United States of America, vol. 89, no. 12, pp. 5685-5689. http://dx.doi. org/10.1073/pnas.89.12.5685. PMid:1608980.

DESANTIS, T.Z., HUGENHOLTZ, P., LARSEN, N., ROJAS, M., BRODIE, E.L., KELLER, K., HUBER, T., DALEVI, D., HU, P. and ANDERSEN, G.L., 2006. Greengenes, a chimera-checked 16S rRNA gene database and workbench compatible with ARB. Applied and Environmental Microbiology, vol. 72, no. 7, pp. 5069-5072. http://dx.doi.org/10.1128/AEM.03006-05. PMid:16820507.

ENGELBREKTSON, A., KUNIN, V., WRIGHTON, K.C., ZVENIGORODSKY, N., CHEN, F., OCHMAN, H. and HUGENHOLTZ, P., 2010. Experimental factors affecting PCR-based estimates of microbial species richness and evenness. The ISME Journal, vol. 4, no. 5, pp. 642-647. http://dx.doi.org/10.1038/ismej.2009.153. PMid:20090784.

ESTEVES, F.A. (2011). Fundamentos de limnologia. 3. ed. Rio de Janeiro: Interciência. Sedimentos Límnicos. pp. 339-354.

FAN, X. and XING, P., 2016. Differences in the composition of archaeal communities in sediments from contrasting zones of Lake Taihu. Frontiers in Microbiology, vol. 7, pp. 1510. http:// dx.doi.org/10.3389/fmicb.2016.01510. PMid:27708641.

FERRY, J.G., 2011. Fundamentals of methanogenic pathways that are key to the biomethanation of complex biomass. Current Opinion in Biotechnology, vol. 22, no. 3, pp. 351-357. http:// dx.doi.org/10.1016/j.copbio.2011.04.011. PMid:21555213.

FRANK, J.A., REICH, C.I., SHARMA, S., WEISBAUM, J.S., WILSON, B.A. and OLSEN, G.J., 2008. Critical evaluation of two primers 
commonly used for amplification of bacterial 16S rRNA genes. Applied and Environmental Microbiology, vol. 74, no. 8, pp. 24612470. http://dx.doi.org/10.1128/AEM.02272-07. PMid:18296538.

GANTNER, S., ANDERSSON, A.F., ALONSO-SÁEZ, L. and BERTILSSON, S., 2011. Novel primers for 16S rRNA-based archaeal community analyses in environmental samples. Journal of Microbiological Methods, vol. 84, no. 1, pp. 12-18. http://dx.doi.org/10.1016/j. mimet.2010.10.001. PMid:20940022.

GARRIDO-CARDENAS, J.A. and MANZANO-AGUGLIARO, F., 2017. The metagenomics worldwide research. Current Genetics, vol. 63, no. 5, pp. 819-829. http://dx.doi.org/10.1007/s00294-0170693-8. PMid:28401295.

GROSSKOPF, R., JANSSEN, P.H. and LIESACK, W., 1998. Diversity and structure of the methanogenic community in anoxic rice paddy soil microcosms as examined by cultivation and direct 16S rRNA gene sequence retrieval. Applied and Environmental Microbiology, vol. 64, no. 3, pp. 960-969. http://dx.doi. org/10.1128/AEM.64.3.960-969.1998. PMid:9501436.

HONG, S., BUNGE, J., LESLIN, C., JEON, S. and EPSTEIN, S.S., 2009. Polymerase chain reaction primers miss half of rRNA microbial diversity. The ISME Journal, vol. 3, no. 12, pp. 1365-1373. http:// dx.doi.org/10.1038/ismej.2009.89. PMid:19693101.

HU, A., HOU, L. and YU, C.P., 2015. Biogeography of planktonic and benthic archaeal communities in a subtropical eutrophic estuary of China. Microbial Ecology, vol. 70, no. 2, pp. 322-335. http://dx.doi.org/10.1007/s00248-015-0597-4. PMid:25805214.

HUG, L.A., BAKER, B.J., ANANTHARAMAN, K., BROWN, C.T., PROBST, A.J., CASTELLE, C.J., BUTTERFIELD, C.N., HERNSDORF, A.W., AMANO, Y., ISE, K., SUZUKI, Y., DUDEK, N., RELMAN, D.A., FINSTAD, K.M., AMUNDSON, R., THOMAS, B.C. and BANFIELD, J.F., 2016. A new view of the tree of life. Nature Microbiology, vol. 1 , no. 5, pp. 16048. http://dx.doi.org/10.1038/nmicrobiol.2016.48. PMid:27572647.

JEYANATHAN, J., KIRS, M., RONIMUS, R.S., HOSKIN, S.O. and JANSSEN, P.H., 2011. Methanogen community structure in the rumens of farmed sheep, cattle and red deer fed different diets. FEMS Microbiology Ecology, vol. 76, no. 2, pp. 311-326. http://dx.doi. org/10.1111/j.1574-6941.2011.01056.x. PMid:21255054.

KENNEDY, K., HALL, M.W., LYNCH, M.D., MORENO-HAGELSIEB, G. and NEUFELD, J.D., 2014. Evaluating bias of illumina-based bacterial 16S rRNA gene profiles. Applied and Environmental Microbiology, vol. 80, no. 18, pp. 5717-5722. http://dx.doi. org/10.1128/AEM.01451-14. PMid:25002428.

KLINDWORTH, A., PRUESSE, E., SCHWEER, T., PEPLIES, J., QUAST, C., HORN, M. and GLÖCKNER, F.O., 2013. Evaluation of general 16S ribosomal RNA gene PCR primers for classical and nextgeneration sequencing-based diversity studies. Nucleic Acids Research, vol. 41, no. 1, pp. e1. http://dx.doi.org/10.1093/nar/ gks808. PMid:22933715.

KOLGANOVA, T.V., KUZNETSOV, B.B. and TUROVA, T.P., 2002. Designing and testing oligonucleotide primers for amplification and sequencing of archaeal 16S rRNA genes. Mikrobiologiia, vol. 71, no. 2, pp. 283-286. PMid:12024834.

LARKIN, M.A., BLACKSHIELDS, G., BROWN, N.P., CHENNA, R., MCGETTIGAN, P.A., MCWILLIAM, H., VALENTIN, F., WALLACE, I.M., WILM, A., LOPEZ, R., THOMPSON, J.D., GIBSON, T.J. and HIGGINS, D.G., 2007. Clustal W and Clustal X version 2.0. Bioinformatics, vol. 23, no. 21, pp. 2947-2948. http://dx.doi. org/10.1093/bioinformatics/btm404. PMid:17846036.

LASKAR, F., DAS PURKAYASTHA, S., SEN, A., BHATTACHARYA, M.K. and MISRA, B.B., 2018. Diversity of methanogenic archaea in freshwater sediments of lacustrine ecosystems. Journal of
Basic Microbiology, vol. 58, no. 2, pp. 101-119. http://dx.doi. org/10.1002/jobm.201700341. PMid:29083035.

LLOYD, K.G., STEEN, A.D., LADAU, J., YIN, J. and CROSBY, L., 2018. Phylogenetically novel uncultured microbial cells dominate earth microbiomes. mSystems, vol. 3, no. 5. http://dx.doi. org/10.1128/mSystems.00055-18. PMid:30273414.

MUYZER, G., DE WAAL, E.C. and UITTERLINDEN, A.G., 1993. Profiling of complex microbial populations by denaturing gradient gel electrophoresis analysis of polymerase chain reaction-amplified genes coding for $16 \mathrm{~S}$ rRNA. Applied and Environmental Microbiology, vol. 59, no. 3, pp.695-700. http:// dx.doi.org/10.1128/aem.59.3.695-700.1993. PMid:7683183.

NISHIZAWA, T., KOMATSUZAKI, M., KANEKO, N. and OHTA, H., 2008. Archaeal diversity of upland rice field soils assessed by the terminal restriction fragment length polymorphism method combined with real time quantitative-pcr and a clone library analysis. Microbes and Environments, vol. 23, no. 3, pp. 237243. http://dx.doi.org/10.1264/jsme2.23.237. PMid:21558714.

QUAST, C., PRUESSE, E., YILMAZ, P., GERKEN, J., SCHWEER, T., YARZA, P., PEPLIES, J. and GLÖCKNER, F.O., 2013. The SILVA ribosomal RNA gene database project: improved data processing and web-based tools. Nucleic Acids Research, vol. 41, pp. D590-D596. PMid:23193283.

RAPPÉ, M.S. and GIOVANNONI, S.J., 2003. The uncultured microbial majority. Annual Review of Microbiology, vol. 57, no. 1, pp. 369394. http://dx.doi.org/10.1146/annurev.micro.57.030502.090759. PMid:14527284.

RODRIGUES, T., CATÃO, E., BUSTAMANTE, M.M., QUIRINO, B.F., KRUGER, R.H. and KYAW, C.M., 2014. Seasonal effects in a lake sediment archaeal community of the Brazilian Savanna. Archaea (Vancouver, B.C.), vol. 2014, pp. 957145. http://dx.doi. org/10.1155/2014/957145. PMid:25147480.

SANSONE, F.J. and MARTENS, C.S., 1982. Volatile fatty acid cycling in organic-rich marine sediments. Geochimica et Cosmochimica Acta, vol. 46, no. 9, pp. 1575-1589. http://dx.doi.org/10.1016/00167037(82)90315-5.

SANTOS, H.R.M., ARGOLO, C.S., ARGÔLO-FILHO, R.C. and LOGUERCIO, L.L., 2019. A 16S rDNA PCR-based theoretical to actual delta approach on culturable mock communities revealed severe losses of diversity information. BMC Microbiology, vol. 19, no. 1, pp. 74. http://dx.doi.org/10.1186/s12866-019-1446-2. PMid:30961521.

SCHLOSS, P.D., WESTCOTT, S.L., RYABIN, T., HALL, J.R., HARTMANN, M., HOLLISTER, E.B., LESNIEWSKI, R.A., OAKLEY, B.B., PARKS, D.H., ROBINSON, C.J., SAHL, J.W., STRES, B., THALLINGER, G.G., VAN HORN, D.J. and WEBER, C.F., 2009. Introducing mothur: opensource, platform-independent, community-supported software for describing and comparing microbial communities. Applied and Environmental Microbiology, vol. 75, no. 23, pp.7537-7541. http://dx.doi.org/10.1128/AEM.01541-09. PMid:19801464.

STREIT, W.R. and SCHMITZ, R.A., 2004. Metagenomics -- the key to the uncultured microbes. Current Opinion in Microbiology, vol. 7, no. 5, pp. 492-498. http://dx.doi.org/10.1016/j.mib.2004.08.002. PMiD: 15451504.

THOMAZ, S.M., PEREIRA, G. and PAGIORO, T.A., 2001. Microbial respiration and chemical composition of different sediment fractions in waterbodies of the upper Paraná river floodpain, Brazil. Brazilian Journal of Biology = Revista Brasileira de Biologia, vol. 61, no. 2, pp. 277-286. http://dx.doi.org/10.1590/S003471082001000200010. PMid:11514895.

TUPINAMBÁ, D.D., CANTÃO, M.E., COSTA, O.Y., BERGMANN, J.C., KRUGER, R.H., KYAW, C.M., BARRETO, C.C. and QUIRINO, B.F., 2016. Archaeal community changes associated with cultivation of 
Amazon forest soil with oil Palm. Archaea, vol. 2016, pp. 3762159. http://dx.doi.org/10.1155/2016/3762159. PMid:27006640.

WU, R.N., MENG, H., WANG, Y.F., LAN, W. and GU, J.D., 2017. A more comprehensive community of Ammonia-Oxidizing Archaea (AOA) Revealed by Genomic DNA and RNA Analyses of amoA gene in Subtropical Acidic Forest soils. Microbial Ecology, vol. 74, no. 4, pp. 910-922. http://dx.doi.org/10.1007/s00248-0171045-4. PMid:28808742.
ZHOU, Z., PAN, J., WANG, F., GU, J.D. and LI, M., 2018. Bathyarchaeota: globally distributed metabolic generalists in anoxic environments. FEMS Microbiology Reviews, vol. 42, no. 5, pp. 639655. http://dx.doi.org/10.1093/femsre/fuy023. PMid:29790926.

ZHU, D.-L., SUN, C. and HE, H., 2012. Detection methanogens in newly settled sediments from Xuanwu Lake in Nanjing, China. Current Microbiology, vol. 64, no. 6, pp. 539-544. http://dx.doi. org/10.1007/s00284-012-0103-x. PMid:22392597. 